\title{
PENGEMBANGAN DAN PELATIHAN MENGGUNAKAN MODEL BISNIS CANVAS BAGI SISWA/I SMK SANTO LEO MANGGA BESAR JAKARTA
}

\author{
Ary Satria Pamungkas', Hannes Widjaya ${ }^{2}$, Hendra Wiyanto ${ }^{3}$, dan Herlina Budiono ${ }^{4}$
}

\author{
${ }^{1}$ Jurusan Manajemen, Universitas Tarumanagara Jakarta \\ Email: aryp@fe.untar.ac.id \\ 2 Jurusan Manajemen, Universitas Tarumanagara Jakarta \\ Email: hannesw@untar.ac.id \\ ${ }^{3}$ Jurusan Manajemen, Universitas Tarumanagara Jakarta \\ Email: hendraw@fe.untar.ac.id \\ ${ }^{4}$ Jurusan Manajemen, Universitas Tarumanagara Jakarta \\ Email: herlinab@fe.untar.ac.id
}

\begin{abstract}
The development of entrepreneurship in the country is diverse and demands change for changes according to the latest advances in technology and information. The role of entrepreneurship for economic growth in a time when a changing world demands change as well. The younger generation is a priority target in Entrepreneurship Education. By fostering an entrepreneurial spirit and changing the thinking pattern of the younger generation, it is hoped that it will slowly but surely reduce the unemployment rate. The proportion of the population whose education is quite good has increased, but the increase has not been satisfactory, because there are still some of them are elderly, and the proportion with low education is quite large. The solution to facing the challenges of this big change is none other than the mastery of information, technology and international markets. A seemingly simple but difficult and timeconsuming way to fundamentally transform Indonesian entrepreneurship by transforming low potential into high quality entrepreneurs. This is not only increasing output and per capita income, but also awakens the spirit of entrepreneurship, independence, work, and development of the national economy. The era of rapid technology plays an important role in encouraging new entrepreneurialism. SMK Santo Leo students have succeeded in making a canvas model for business which is expected to be achieved per group according to the expectations of PKM team.
\end{abstract}

Keywords: Business Canvas Model.

\begin{abstract}
ABSTRAK
Perkembangan kewirausahaan di tanah air beragam dan menuntut perubahan demi perubahan sesuai kemajuan teknologi dan informasi terkini. Peranan kewirausahaan bagi pertumbuhan ekonomi di saat dunia yang terus berubah menuntut perubahan pula. Generasi muda menjadi target prioritas dalam Pendidikan Kewirausahaan. Dengan menumbuhkan jiwa kewirausahaan serta mengubah pola berpikir generasi muda diharapkan perlahan namun pasti akan menurunkan tingkat pengangguran. Proporsi penduduk yang pendidikannya cukup baik mengalami peningkatan, tetapi peningkatan tersebut belum memuaskan, karena masih ada sebagian yang belum mengenyam pendidikan formal, kebanyakan usia sudah lanjut, dan proporsi yang pendidikannya rendah cukup besar. Solusi menghadapi tantangan perubahan yang besar ini tidak lain adalah dalam penguasaan informasi, teknologi, dan pasar internasional. Cara yang terlihat sederhana namun sulit dan membutuhkan waktu untuk mengubah secara mendasar wirausaha Indonesia dengan mengubah potensi yang rendah menjadi wirausaha yang berkualitas tinggi. Hal tersebut tidak sekedar meningkatkan output dan pendapatan per kapita, melainkan kebangkitan semangat jiwa kewirausahaan, berdikari, karya, serta pengembangan perekonomian nasional. Era teknologi yang pesat berperan penting dalam mendorong entrepreneurial baru. Oleh karena itu program Pengabdian kepada masyarakat ini mempunyai program untuk menumbuhkan dan menciptakan ide-ide kreatif dan unik kepada generasi muda khususnya siswa-siswi SMK Santo Leo Mangga Besar agar dapat memiliki minat dan pengetahuan dasar mengenai perencanaan kewirausahaan dengan menggunakan model canvas. Siswa siswi SMK Santo Leo berhasil membuat model canvas untuk bisnis yang diharapkan per kelompok dapat tercapai sesuai harapan tim PKM.
\end{abstract}

Kata Kunci: Model Bisnis Canvas 


\section{PENDAHULUAN}

Pengangguran telah menjadi perhatian masalah bagi negara-negara secara universal tidak terkecuali Indonesia. Di Indonesia, berbagai upaya dan kebijakan serta strategi pemerintah yang telah diterapkan guna mengurangi pengangguran belum dapat sepenuhnya menekan jumlah pengangguran. Pertambahan penduduk yang tidak disertai dengan ketersediaan lapangan pekerjaan menyebabkan naiknya tingkat pengangguran.

Berdasarkan data terakhir bahwa tingkat pengangguran terbuka (BPS, Februari 2020) untuk SLTA Umum/SMU sebesar 1.680.794 jiwa dan untuk SLTA Kejuruan/SMK sebesar 1.381.964 jiwa. Dengan tingkat pengangguran yang meningkat namun bila tidak disertai pembimbingan dalam mencari pekerjaan maupun penciptaan lapangan pekerjaan, akan memperburuk kondisi perekonomian secara menyeluruh.

Salah satu cara yang dapat ditempuh untuk mengurangi jumlah pengangguran yang ada di Indonesia adalah berwirausaha. Dengan adanya wirausaha, dapat mengurangi jumlah pengangguran sehingga dapat pula mengurangi beban pemerintah dalam upaya untuk mengurangi pengangguran. Dengan demikian, dapat menciptakan lapangan pekerjaan yang baru serta berpeluang mendapatkan penghasilan yang besar bagi wirausahawan sehingga berkontribusi kepada perekonomian negara.

Generasi muda menjadi target prioritas dalam Pendidikan Kewirausahaan. Dengan menumbuhkan jiwa kewirausahaan serta mengubah pola berpikir generasi muda diharapkan perlahan namun pasti akan menurunkan tingkat pengangguran. Pemerintah telah menerapkan pendidikan kewirausahaan di berbagai tingkatan sekolah yang bertujuan menciptakan wirausahawan muda yang berpengalaman dan terampil untuk menyerap tenaga kerja sehingga mengurangi pengangguran.

Pada tahun 1971 hingga 1990, proporsi penduduk yang pendidikannya cukup baik mengalami peningkatan. Tetapi siswa/i sadar bahwa angka tersebut belum memuaskan, karena masih ada sebagian yang belum mengenyam pendidikan formal, kebanyakan usia sudah lanjut, dan proporsi yang pendidikannya rendah cukup besar (Khasali, 2010). Solusi menghadapi tantangan perubahan yang besar ini tidak adalah dalam penguasaan informasi, teknologi, dan pasar internasional. Cara yang terlihat sederhana namun sulit dan membutuhkan waktu untuk mengubah secara mendasar wirausaha Indonesia dengan mengubah potensi yang rendah menjadi wirausaha yang berkualitas tinggi.

Sunarya (2012) mengemukakan "masyarakat harus 100 persen tamat SD, 65 persen tamat SLTA, dan 35 persen berijazah perguruan tinggi, dan dari 35 persen itu sebagian besar di bidang keahlian sains dan teknologi." Kerja keras diperlukan untuk mencapai tingkat yang diharapkan. Tujuan pendidikan kewirausahaan adalah untuk melatih siswa memperoleh keterampilan, ide, dan kemampuan manajerial, dan kapasitas wirausaha daripada dipekerjakan untuk dibayar (Owoseni \& Akambi, 2010). Sumber daya berkualitas sebagai wirausaha yang mampu menyerap informasi dan teknologi, serta etos kerja dan mental bersaing yang sehat. Langkah selanjutnya adalah menciptakan kesempatan kerja yang sesuai dengan kualitas tersebut.

Dengan metode BMC bagi wirausaha (Hery, 2017) dapat menjadi salah satu pendekatan pemecahan masalah dalam pengembangan yang bisa diadopsi. Model ini mensyaratkan secara mutlak bahwa memandang bisnis harus secara utuh. Wirausaha adalah pelaku, pelaksana, dan penikmat pembangunan, dengan menyertakan suasana kebebasan dan keterbukaan sehingga merangsang tumbuhnya entrepreunership. 
Model bisnis merupakan sebuah gambaran perihal bagaimana sebuah perusahaan memperoleh sebuah nilai tambah, termasuk kombinasi dari produk, service, citra, distribusi dan sumber daya serta infrastruktur di dunia kerja. Demikian pula konsep model bisnis telah diposisikan antara input yang digunakan oleh perusahaan untuk memperoleh output ekonomi (Afuah, 2004). Model bisnis sangat penting bagi calon wirausaha pemula karena bisa dilihat beberapa keuntungannya, yaitu: pertama, dengan adanya model bisnis dapat membantu para pelaku usaha untuk memperoleh informasi mengenai bagaimana (how), dimana (where) dan kapan (when) produk tersebut berfungsi dengan baik. Kemudian merancang business model yang baik untuk bersaing dengan kompetitor lain. Maka dengan adanya keuntungan tersebut dapat membantu perusahaan memenangkan daya saing di pasar.

Dari permasalahan mitra yang ada dan telah disampaikan alasan diadakannya PKM di SMK Santo Leo Jakarta adalah untuk:

1. Untuk meningkatkan serta mengembangkan potensi wirausaha muda di SMK Santo Leo Jakarta.

2. Untuk mempertahankan eksistensi mata pelajaran kewirausahaan yang telah diajarkan di SMK Santo Leo Jakarta yang tentunya dapat diharapkan banyak inovasi produk yang bermunculan.

3. Dengan berkembangnya start-up atau para wirausaha muda setelah lulus SMK diharapkan dapat siswa/i mulai membuka usaha serta menyerap sumber daya manusia dan mengurangi angka pengangguran serta meningkatkan nilai ekonomi masyarakat sekitar.

\section{METODE PELAKSANAAN PKM}

Langkah awal dalam pelatihan bisnis BMC adalah membentuk siswa/i memiliki pola berpikir sebagai pebisnis yang sukses. Dimana seorang entrepreneur atau calon wirausaha haruslah memiliki pola berpikir atau mindset yang lebih productive, creative dan innovative. Kenapa harus begitu? Karena dalam menjalani sebuah bisnis/usaha tidak akan selamanya berjalan dengan mulus. Paling tidak ada sedikit batu kerikil yang mengganjal sehingga bisa mengakibatkan bisnis berhenti atau berjalan di tempat.

Tujuan dari pelatihan bisnis BMC adalah pemecahan, solusi, atau jalan alternatif yang dapat digunakan untuk membentuk pola berpikir para siswa/i yang awalnya kurang percaya diri semakin berkembang menjadi memenuhi standar seorang entrepreneur yang ulet dan kuat/tahan banting. Nantinya setelah menempuh pelatihan usaha/bisnis siswa/i dapat siap baik mental, pikiran, serta finansial dalam bersaing di pasar usaha/bisnis yang semakin ketat. Selain itu, pelatihan bisnis juga akan membuat siswa/i mendapatkan manfaat apa saja? Dokumentasi pelaksanaan PKM dapat dilihat pada Gambar 1.

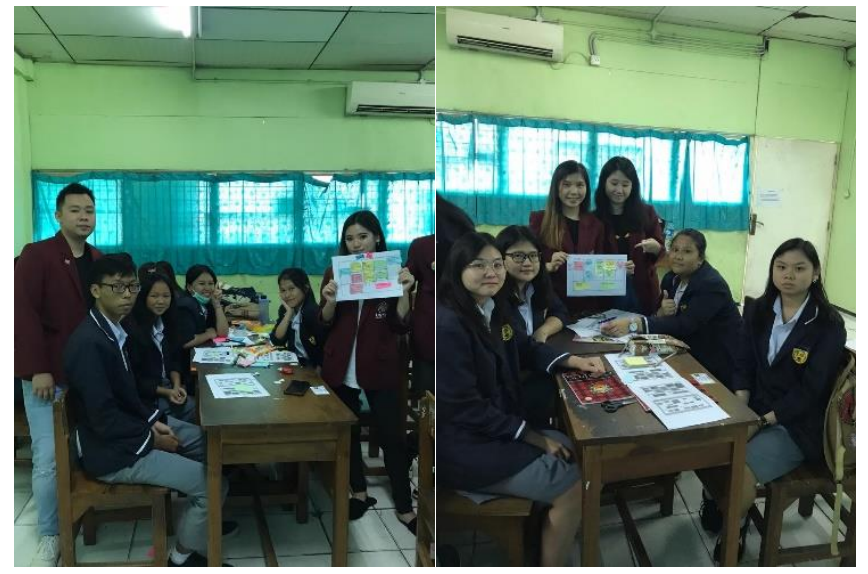

Gambar 1. Siswa/i Bersama Mahasiswa Menunjukkan Hasil BMC yang Dibuat 
Manfaat pelatihan BMC ini pada dasarnya bertujuan untuk menjadi pebisnis sukses yang handal dan tahan banting tentunya siswa/i harus melewati beberapa proses dan tahapan-tahapan yang bisa dibilang cukup panjang. Akan tiba masanya siswa/i jatuh bangun membangun bisnis dan bahkan banyak hal-hal yang dirasa akan mustahil untuk dilakukan. Siswa/i harus menambah pengalaman terlebih dahulu dan belajar dan bertanya pada orang yang lebih berpengalaman. Barulah para siswa/i bisa mempraktekannya untuk bisnis siswa/i sendiri. Tapi dengan mengikuti pelatihan bisnis, para calon wirausaha muda akan mengambil sebuah langkah sangat tepat. Terutama bagi pelaku bisnis pemula yang belum memiliki pengetahuan yang cukup dalam menjalankan usaha/bisnis. Sehingga siswa/i dapat bekerja secara maksimal, tidak ragu mengambil langkah yang perlu, tanpa meraba-raba langkah apa yang harus dilakukan dan mampu memaksimalkan waktu yang ada. Belajar dari ahlinya adalah salah satu hal yang bisa mempercepat bisnis siswa/i untuk berkembang karena siswa/i akan seperti melompati jebakan-jebakan bisnis yang bisa memperlambat laju jalan bisnis.

Pelatihan bisnis bertujuan untuk meningkatkan kinerja siswa/i dalam menghadapi pekerjaan, sehingga menjadi lebih efektif dan efisien, serta mampu menghasilkan inovasi-inovasi baru bagi bisnis siswa/i. Akan ada banyak ilmu seperti soft skill dan hard skill yang bisa siswa/i pelajari untuk diterapkan dalam bisnis yang sedang dibangun. Apalagi sekarang banyak yang menawarkan kelas pelatihan bisnis dengan materi yang spesifik sehingga bisa siswa/i sesuaikan dengan kebutuhan. Dengan berkembangnya teknologi, kelas tersebut juga bisa diakses secara online sehingga bisa menghemat waktu dan bisa siswa/i lakukan di mana saja.

Sikap juga merupakan kunci penting dalam berbisnis. Dengan mengikuti pelatihan bisnis, para siswa/i akan terbentuk sikap dan tingkah laku dalam menjalin hubungan baik antar calon wirausaha, calon wirausaha dengan partner bisnis, calon wirausaha dengan karyawan, maupun calon wirausaha dengan konsumen. Pelatihan bisnis membuat siswa/i bertemu dengan banyak pebisnis lain dengan latar belakang yang bermacam-macam. Selain menambah network, siswa/i juga menjadi belajar bagaimana menyikapi situasi dan orang yang berbeda-beda. Mengingat kepercayaan juga dibangun melalui sikap siswa/i terhadap orang lain terutama dalam konteks ini adalah saat berbisnis.

Tanpa dicari, masalah akan selalu muncul dalam siswa/i menjalankan bisnis. Dengan mengikuti pelatihan bisnis sebelum usaha ini, siswa/i akan terbantu untuk mampu memecahkan masalahmasalah operasional perusahaan sehari-hari sampai menemukan solusi untuk bisnis dalam jangka panjang. Akan ada banyak masalah yang muncul tanpa siswa/i sadari sebelumnya. Belajar dari ahlinya akan membuat persiapan siswa/i terhadap masalah-masalah tersebut menjadi lebih matang. Selain itu, siswa/i juga bisa mencegah masalah yang biasanya muncul berdasarkan saran dari yang sudah berpengalaman atau dari rekan sesama peserta pelatihan bisnis tersebut. Karena setiap bisnis pasti berbeda, belajar dari sebanyak-banyaknya orang akan membuat siswa/i lebih bijak.

Pelatihan bisnis BMC mempunyai tujuan jangka pendek dan jangka panjang, yaitu mempersiapkan para calon wirausaha memperoleh keahlian dalam bidang tertentu yang dibutuhkan usahanya (Osterwalder, 2012). Misalnya seperti mengambil beberapa sertifikasi dalam bidang yang dibutuhkan. Hal ini akan bermanfaat tergantung pada bidang apa yang digeluti. Dari pelatihan siswa/i juga bisa mengasah kemampuan agar lebih baik. Dan bila kemampuan serta pengetahuan wirausaha yang siswa/i miliki mumpuni, siswa/i dapat memperoleh rasa aman dan menimbulkan kepuasan tersendiri dalam menjalankan usahanya. 
Selain manfaat tersebut di atas, ada juga keuntungan lain dari mengikuti suatu pelatihan bisnis BMC ini. Misalnya bagaimana menemukan partner atau rekan kerja dan mentor yang tepat untuk bisnis yang akan atau sedang dijalani. Tapi ada hal utama yang perlu diperhatikan oleh para calon wirausaha, yaitu pastikan bahwa siswa/i sudah benar-benar memahami usaha yang ingin atau sedang dijalani. Sehingga para calon wirausaha tahu dan mengerti benar pelatihan wirausaha semacam apa yang harus diikuti.

Apalagi bisnis sekarang ini menawarkan banyak sekali kesempatan untuk membuat anak-anak muda menjadi wirausahawan yang sukses dengan berbagai macam jenis bisnis. Bisa siswa/i lihat bagaimana menjamurnya jual beli online sebagai salah satu solusi yang praktis. Anak muda yang paling memahami hal ini. Animo masyarakat akan hal ini juga termasuk tinggi mengingat dengan berbelanja secara online, semua bisa dilakukan dalam genggaman secara praktis. Terbukti dengan naiknya minat masyarakat Indonesia pada jual-beli online. Lalu pertanyaan muncul bagi mereka yang memang tertarik untuk menekuni bisnis online ini.

Pelatihan bisnis saat ini ini juga biasanya tersedia secara berkelanjutan, ada juga yang langsung praktek agar lebih mendalam. Para siswa/i bisa mengikuti dengan menentukan jenis bisnis yang akan dijalankan terlebih dahulu. Sedikit tips yang bisa diikuti yaitu mengenai menjalankan bisnis yang lebih spesifik. Lebih spesifik di sini berarti bahwa bisnis harus mengerucut pada jenis bisnis yang akan dijalankan. Setidaknya dengan semakin spesifik produk yang akan dijual, maka akan membuat konsumen lebih mengenal dan mengandalkan brand tersebut. Model BMC dapat dilihat pada Gambar 2.

Menurut Osterwalder (2012) ada 9 komponen yang terdapat dalam BMC yang akan diberikan dalam pelatihan ini adalah sebagai berikut:

1. Customer Segments (Segmentasi Konsumen)

Elemen pertama yang harus dimiliki saat memulai bisnis model kanvas ini adalah penentuan segmen pelanggan yang akan menjadi target bisnis. Misalnya, suatu maskapai penerbangan mengeluarkan 2 produk untuk memenuhi kebutuhan 2 segmen pelanggan yang berbeda, atau ada 2 stasiun televisi yang menyajikan 2 acara berbeda untuk memenuhi segmen pelanggan yang berbeda.

2. Value Proposition (Proposisi Nilai Konsumen)

Adalah sekat yang merupakan keunggulan produk, apa saja yang sesungguhnya menjadi poin yang dapat mendatangkan manfaat yang ditawarkan perusahaan bagi customer segment-nya. Hal ini menjadi kesempatan untuk menjabarkan kekuatan dan keunggulan yang membedakan bisnis dengan bisnis yang lain.

3. Channels (Saluran)

Channel atau saluran adalah bagaimana dapat menyampaikan produk hingga ke konsumen. Melalui penggunaan channels yang tepat, baru bisa menyampaikan value propositions kepada customer segments. Jadi, cobalah pikirkan channels yang ingin digunakan dengan baik, karena penentuan channels adalah salah satu elemen penting bagi keberhasilan sebuah bisnis.

4. Revenue Streams (Sumber Pendapatan)

Revenue streams adalah bagian yang paling penting/vital, di mana organisasi memperoleh pendapatan dari konsumen. Elemen ini perlu dikelola semaksimal mungkin guna peningkatkan pendapatan usaha/bisnis. Jangan sampai ada bahan baku, produk, atau kinerja yang tidak dimanfaatkan secara maksimal.

5. Key Resource (Sumber Daya) 
Key resource adalah sekat dalam bisnis model kanvas yang berisikan daftar sumber daya yang sebaiknya direncanakan dan dimiliki perusahaan untuk mewujudkan value proposition. Semua jenis sumber daya, mulai dari pengelolaan bahan baku, penataan SDM, dan penataan proses operasional menjadi perhatian dalam membuat model bisnis.

6. Customer Relationship (Hubungan Konsumen)

Ini merupakan elemen di mana perusahaan menjalin ikatan dengan konsumen. Perlu pengawasan yang ketat dan intensif agar konsumen tidak berpaling ke bisnis yang lain hanya karena jalinan hubungan yang kurang baik.

7. Key Activities (Aktivitas yang Dijalankan)

Key activities adalah semua aktivitas yang berhubungan dengan produktivitas usaha/bisnis yang berkaitan dengan sebuah produk, di mana kegiatan utamanya adalah menghasilkan proposisi nilai.

8. Key Partnership (Kerjasama)

Elemen ini berfungsi untuk pengorganisasian aliran suatu barang atau layanan lainnya. Posisi-posisi partner kunci tersebut bermanfaat untuk efisiensi dan efektivitas dari key activities yang telah dibuat. Tak ada salahnya menjalin hubungan baik untuk menciptakan siklus bisnis sesuai dengan ekspektasi.

9. Cost Structure (Struktur Biaya)

Elemen terakhir yang sama pentingnya dengan kedelapan elemen lain di atas adalah struktur pembiayaan bisnis. Mengelola biaya secara efisien akan membuat usaha/bisnis yang dikelola menjadi lebih hemat dan dapat meminimalkan risiko kerugian/loss. Hal ini juga dapat menentukan proposisi nilai yang tepat untuk pelanggan.

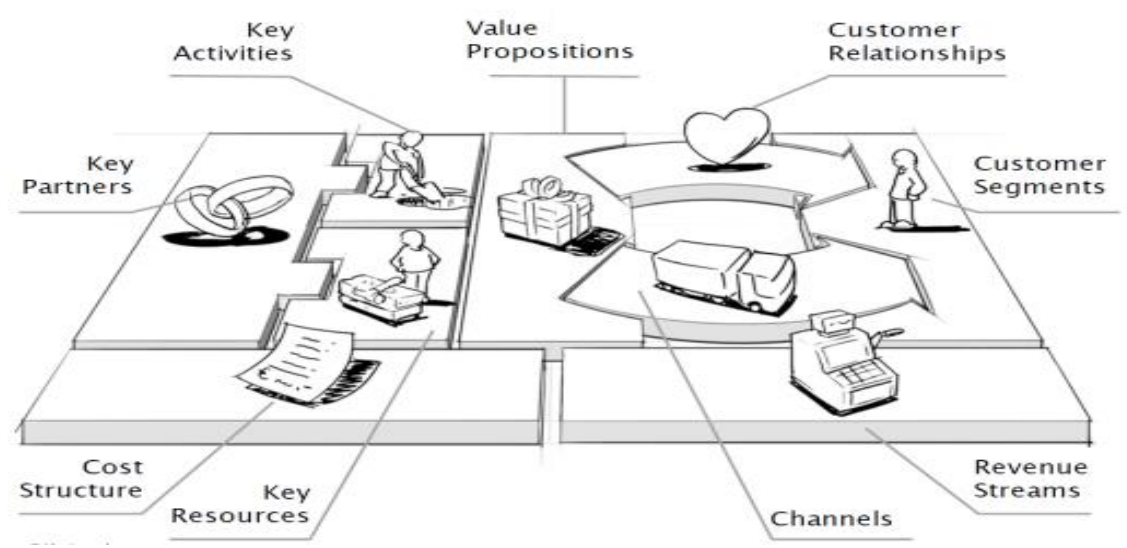

Gambar 2. Model BMC

\section{KESIMPULAN DAN SARAN}

Terdapat beberapa kesimpulan dari pelatihan Business Model Canvas bagi para siswa/i. antara lain adalah para siswa dapat memperpendek penulisan perencanaan bisnis dengan metode konvensional, pelaku usaha/bisnis akan diharuskan menulis/menguraikan panjang lebar tentang perencanaan bisnis/usaha yang akan dibuat. Sedangkan dengan Business Model Canvas/BMC, para siswa/i hanya perlu mengisi poin-poin perencanaan usaha/bisnis sesuai blok/kotak yang ditetapkan tanpa perlu menguraikan panjang lebar. Penentuan poin penting pun semakin terarah dengan blok/kotak yang telah disediakan.

Meningkatkan fokus para siswa/i terhadap poin terpenting dalam perencanaan bisnis BMC, memfokuskan bisnis/usaha pada elemen strategis yang paling penting dan akan memiliki dampak terbesar pada mendorong pertumbuhan. Sifat visual BMC membantu pemahaman dengan mudah melihat gambaran menyeluruh bisnis/usaha dan dengan demikian melihat area kekuatan dan 
kelemahan tergantung pada input. Membangun model bisnis/usaha sedemikian rupa sehingga keseluruhan terdiri dari dan lebih besar dari jumlah bagian.

Secara tidak langsung mengurangi resiko kekeliruan dalam eksekusi bisnis, Business Model Canvas/BMC dapat dijadikan dokumen blueprint perencanaan bisnis untuk memulai usaha/bisnis. Ketika pelaku usaha/bisnis melakukan eksekusi bisnis, mereka dapat menjadikan Business Model Canvas/BMC akan menjadi panduan untuk menjalani eksekusi bisnis/usaha berdasarkan poin yang telah dirancang sebelumnya. Dengan demikian, perusahaan pun dapat mengurangi resiko kekeliruan dalam eksekusi bisnis.

\section{Ucapan Terima Kasih (Acknowledgement)}

Kami mengucapkan banyak terima kasih kepada Rektor Universitas Tarumanagara, Ketua Lembaga Penelitian dan PKM Universitas Tarumanagara, Dekan dan jajaran pimpinan Fakultas Ekonomi dan Bisnis Universitas Tarumanagara, Kepala Sekolah dan Siswa/i SMK Santo Leo Jakarta, serta semua pihak yang tidak dapat kami sebutkan satu per satu.

\section{REFERENSI}

Badan Pusat Statistik, Tingkat Pengangguran Terbuka Berdasarkan Pendidikan Tertinggi yang Ditamatkan, Februari 2019.

Hery. (2017). Kewirausahaan. Jakarta: PT Grasindo.

Osterwalder, A., \& Pigneur, Y. (2012). Business Model Generation: Membangun Model Bisnis. Jakarta: Elex Media Komputindo.

Rhenal Kasali dkk. (2010). Modul Kewirausahaan Untuk Program Strata I. Jakarta: Mandiri \& Rumah Perubahan.

Sunarya, P. A., Sudaryono, \& Saefullah, A. (2012). Kewirausahaan (Vol. I). Yogyakarta: Penerbit Andi.

Zimmerer, T.W., Scarborough, \& N.M. Wilson D. (2008). Essensials of entrepreneurship and Small Business Management. 5th Ed. Pearson/Prentice Hall, New Jersey. 